Mercator, Fortaleza, v. 16, e16015, 2017.

DOI: https://doi.org/10.4215/rm2017.e16015

ISSN: $1984-2201$

Copyright @ 2002, Universidade Federal do Ceará

\title{
THE HOUSING ISSUE IN BRAZIL
}

\author{
MONTEIRO, Adriana Roseno; ${ }^{*}$ VERAS, Antonio Tolrino de Rezende ${ }^{\mathrm{b}}$
}

(a) Msc. in Geography, University Federal of Rotraima (UFRR). http://lattes.cnpq.br/5441053308612381

(b) Phd in Geography, Lecteur University Federal of Rotraima (UFRR). http://lattes.cnpq.br/9266448165398292

\section{(*) CORRESPONDING AUTHOR}

Address: Universidade Federal de Roraima, Av. Cap. Ene Garcez, 2413, CEP: 69304000 - Boa Vista (RR), Brazil. Tel: (+55 95) 81135676 E-mail: drycaluz@hotmail.com

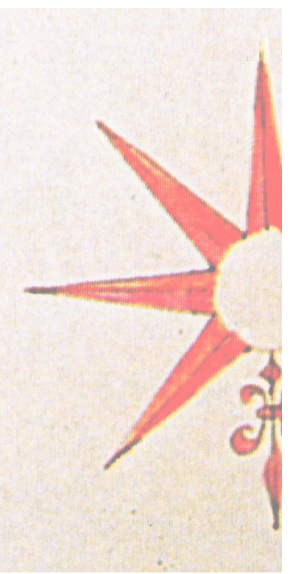

\begin{abstract}
This article discusses housing in Brazil, which is one of the main urban problems in contemporary times. Housing is a high cost commodity with selective access, thus excluding economically disadvantaged social groups. The segregating character that permeates the housing issue is evidenced as a historically established process in our capitalist society. Therefore, the main objective of this research was to analyze the housing situation in Brazil, in view of Brazilian urbanization and the commercialization of urban land and housing, considering that housing is a key issue in public policies, projecting itself as a material form of social inclusion. Thus, this research made it possible to perceive that the housing problem in Brazil has not been totally solved yet. To this end, the provision of housing for low income families is indispensable, through well-developed and effective public housing policies that guarantee social development, combat poverty and seek a better quality of life for all citizens.
\end{abstract}

Keywords: Housing. Public Housing Policies. Social inclusion.

\section{RESUMO/ RESUMEN}

\section{A QUESTÃO HABITACIONAL NO BRASIL}

O presente artigo discute a habitação no Brasil, um dos principais problemas urbanos na contemporaneidade. A habitação é um bem de custo elevado e acesso seletivo, excluindo assim os grupos sociais menos favorecidos economicamente. Por conseguinte, esta pesquisa teve então como objetivo principal fazer uma análise da questão habitacional no Brasil, face à urbanização brasileira e a mercantilização da terra urbana e da habitação, considerando que a habitacão trata-se de uma questão mister nas políticas públicas, ao se projetar como uma forma material de inclusão social. Assim esta pesquisa permitiu percebermos que o problema habitacional no Brasil ainda não foi totalmente solucionado, sendo indispensável para isso a provisão de moradias para as famílias de baixa renda, através de políticas públicas habitacionais bem elaboradas e eficazes que garantam o desenvolvimento social, o combate à pobreza e busquem uma melhor qualidade de vida a todos os cidadãos.

Palavras-chave: Habitação. Políticas Públicas Habitacionais. Inclusão Social.

\section{LA HABITACIÓN EN BRASIL}

El presente artículo discute la vivienda en Brasil, que se constituye en uno de los principales problemas en la contemporaneidad. La vivienda es un bien de costo elevado y acceso restricto, excluyendo así a los grupos sociales menos favorecidos económicamente. Por consiguiente, esta investigación tuvo entonces, como objetivo principal, realizar un análisis de la cuestión habitacional en Brasil, de cara a la urbanización brasileña y a la mercantilización de la tierra urbana y de la vivienda, considerando que la vivienda se trata de una cuestión imprescindible en las políticas públicas, al proyectarse como una vía material de inclusión social. De esta forma, la investigación permitió que percibiéramos que el problema habitacional en Brasil todavía no ha sido solucionado en su totalidad, siendo indispensable para esto la provisión de moradas para las familias de bajos ingresos, a través de políticas públicas habitacionales bien elaboradas y eficaces que garanticen el desarrollo social, el combate a la pobreza y una búsqueda de una mejor calidad de vida para todos los ciudadanos.

Palabras clave: Vivienda. Políticas Públicas Habitacionales. Inclusión Social. 


\section{INTRODUCTION}

Guaranteeing access to housing to the part of the population considered low income is indispensable to meet the needs of the most vulnerable social groups. This requires effective and continuous housing policies that allow the inclusion of these individuals in the city and their insertion into society.

Therefore, the study of housing issues is part of a relevant contemporary context to understand the fundamental elements for the production and reproduction of geographic space. Thus, the housing problem can be considered one of the main urban social problems, being the subject of various discussions and academic debates.

This work adopted document research and bibliographical surveys as its methodological procedures, which are essential for a scientific study structured on solid theoretical bases by means of surveying and working with primary and secondary data.

The collection of data on the subject was developed through a review of the literature in books, scientific articles, dissertations and theses, as well as through the collection of documentary data, carried out through legislation, reports and other available official documents, contributing to the enrichment of this work. The analysis of all these data was done through the critical and normative bias of geographic science, so that this study will not focus only on descriptive concepts but will also contain a substantially critical content.

Therefore, the main objective of this research was to analyze the housing situation in Brazil, in view of Brazilian urbanization and the commercialization of urban land and housing, to reach the conclusion that housing is a key issue in public policies, by projecting itself as a material form of social inclusion.

Housing policies have passed through various stages throughout history, with progress and setbacks, resulting in periods of depletion of housing programs, especially those destined to the country's less privileged social classes, and in others where there has been an attempt to tackle the deficit in a more incisive way.

Several federal housing programs and projects have been created at the federal level and implemented in several Brazilian cities through the construction of housing estates. However, the problems related to a lack of housing have not yet been fully solved. Considering that the Capitalist city is exclusionary, with totally different scenarios and antagonistic classes, housing is inserted in this context with inequalities manifested in different forms, especially in the form of how urban space is inhabited.

It is noteworthy that the launch of the Minha Casa, Minha Vida (PMCMV) Program by the government of Luís Inácio Lula da Silva in March 2009, created conditions for the expansion of the housing market for families with an income of up to 10 minimum wages, generating new expectations for the area of housing, related both to the number of UHS and the amount of the subsidy.

Taking the aforementioned discussions as a reference, this article is structured in three sections, including the present Introduction and the final considerations, which were developed based on an exploratory study of a qualitative nature, through a literature review:

The first section, entitled "Brazilian urbanization and housing", aims to show how urbanization has been structured in Brazil along a historical trajectory, highlighting its implications for the organization and access to housing by the portion of the population that does not have sufficient financial resources to participate in the formal housing market, thus revealing that this is not a recent problem.

The second section, entitled "The transformation of urban land and housing into commodities", analyzes the insertion of housing into a class-structured, capital-based society, where housing with great added value becomes a product of real estate speculation making the housing market for the low-income population restrictive and exclusionary. 
The third section, entitled "Housing and Social Inclusion", highlights the importance of housing and public facilities and services for all citizens, as a means of guaranteeing well-being, human dignity, equity, citizenship, insertion into society and social inclusion.

By way of a conclusion, the final considerations identify the main themes addressed in the article, such as the urban-industrial process and the disorderly growth of cities, implying urban housing problems and the commodification of urban land, excluding the low income population, thus requiring more efficient public housing policies that allow the social inclusion of all citizens.

\section{BRAZILIAN URBANIZATION AND HOUSING}

Understanding the housing issue in Brazil includes reflecting on urbanization, considering the social, political, economic and ideological aspects that involve this process over time. Therefore, identifying the transformations in the production and structuring of urban space resulting from urbanization helps to unravel the socio-spatial dynamics of cities today.

Due to this, we will initially make some considerations about the influence of the urbanization process on the housing problem, outlining the different types of human habitation. It must be taken in to account that urbanization did not take place at the same time or with the same intensity in all parts of the world. The urbanization process began first in Europe.

For centuries the Roman Empire dominated much of Europe. From the third century, this scenario began to change due to difficulties protecting the borders, so that in 476 , the Heruli, a people of Germanic origin, invaded Rome and deposed the emperor. This was the final step towards the disintegration of the Western Roman Empire. Several independent kingdoms appeared in its place. Feudal society formed in these kingdoms.

The first moment, between the fifth and ninth centuries, was the consolidation of the feudal world, when the kingdoms were formed and social organization crystallized. After this, between the tenth and fifteenth centuries, feudal society began to show signs of change, with the strengthening of cities and commerce and the beginning of the period of the great navigations (fifteenth century).

In the Western world, England, as the main economic power of the seventeenth century, accumulated great wealth, especially with the great navigations, so that in the following century the country had a great availability of capital to apply to industrialization.

In Europe, since the eighteenth century, urbanization developed massively as a result of the Urban-Industrial Revolution, although it only reached its full expansion in the nineteenth century; it took more than a century to acquire the current characteristics of scale and agglomeration.

With the mechanization of the countryside and the accelerated rural exodus, urban centers in a large portion of the European nations that were part of the revolution grew significantly. From this population growth the urban centers became saturated, drastically changing the configuration of the urban landscape, the cities did not absorb the flow of people in a planned way leading to the emergence of marginalized neighborhoods composed of poor workers.

In Brazil, the systemic process of urbanization took three centuries to occur, beginning in the eighteenth century and consolidating from the 1940s and 1950s, in a context of urban-industrialization, when the country was typically configured as rural in terms of housing (SANTOS, 2009).

Urbanization is the transformation process of a society or region into an urban one, therefore it does not only represent the growth of the population of the cities, but also a set of techniques and works that give a city or area of a city infrastructure, planning and administrative organization. Thus, for this to take place, a set of changes are needed that will express themselves both in the city's urban landscape and in people's behavior and lifestyle.

According to Santos (2009) urbanization began in the eighteenth century, however, it was only in the twentieth century and especially since the 1940s that urbanization occurred intensely in Brazil, 
resulting in extensive changes in the morphology and expansion of cities and in the distribution of the population throughout the national territory.

Therefore, we can consider Brazilian urbanization a recent phenomenon, with a significant increase in urbanization rates in the country since 1940, causing changes in the urban structure of Brazilian cities and in the constitution of society.

Brazil is fast becoming a predominantly urban country, which is urbanizing at an increasingly greater speed. In a few decades, demographic census data have confirmed the tendency of an increase the urban population, with a rate of $31.34 \%$, that is, $41,236,315$ people lived in urban areas in 1940. By 2010, the urbanization rate was $84.36 \%$, totaling $160,925,792$ million inhabitants living in cities (IBGE, 1940 to 2010). The data in Figure 1 illustrate this increase in urbanization rates in Brazil from 1940 to 2010.

Figure 1- Graph showing urbanization rates in Brazil from 1940 to 2010

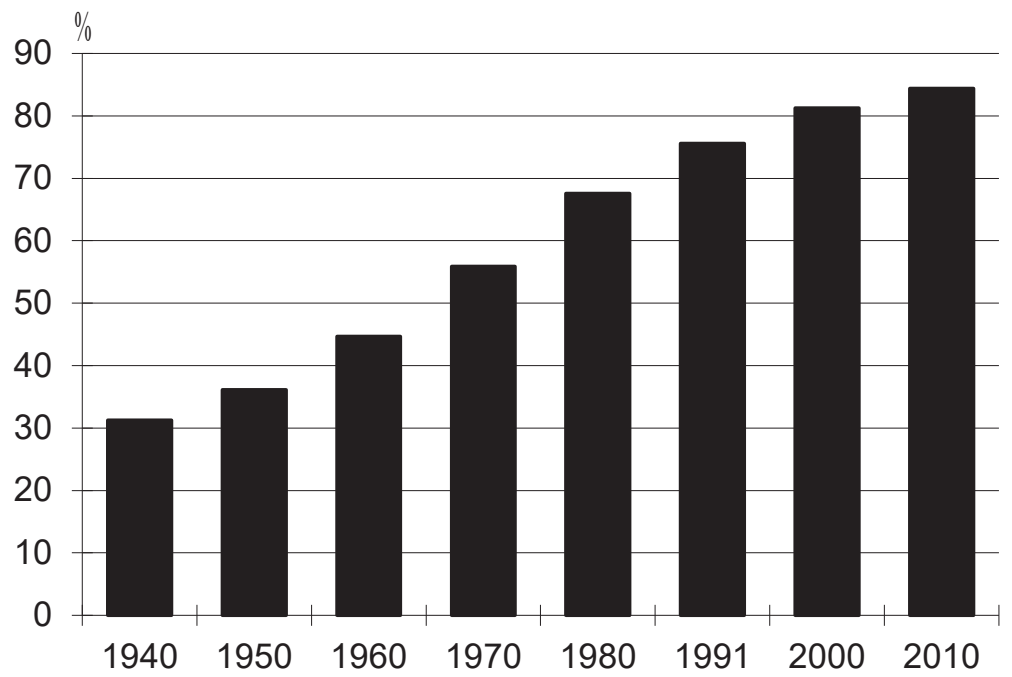

Organization and elaboration: Adriana Roseno Monteiro based on data from the IBGE demographic census.

The data observed in Figure 1 show that the urban population has grown considerably, leading to the affirmation that nowadays Brazil is an urbanized country.

The strong urbanization movement since the end of World War II is a contemporary phenomenon of intense population growth resulting from high birth rates and declining mortality, the main causes of which are health improvements, relative improvements in living standards and urbanization itself (SANTOS, 2009).

The growth of the Brazilian population, reaching 190,755,799 million inhabitants in 2010, can be associated, among other factors, with the birth rates, the reduction of mortality rates, increased life expectancy, related to advances in health and improvements in the population's quality of life (IBGE, 2010). The data in Table 1 show the considerable growth of the Brazilian population over the last decades.

The growth of the Brazilian population has boosted the expansion of cities, as it is allied to a strong urbanization movement, due to an intense rural-urban migratory flow and a tendency towards population agglomeration in urban areas, causing the expansion of the urban network in general.

It is salutary to clarify that the intense rural-urban migration process was a consequence, on the one hand, of the expansion of industrialization in the cities, which attracted a great mass of workers from the countryside. On the other hand, the mechanization of the countryside caused the modernization of agriculture with increased productivity and a reduction in the workforce. Allied to the absence of public policies directed to the countryside, people were forced to move to the cities in search of employment and a better quality of life. The labor that came from the countryside 
acted as a support for the process of low-cost industrialization, a process that was occurring in some Brazilian cities; however, industry was not able to absorb all this contingent.

Table 1 - Showing the increase of the Brazilian population in the period from 1940 to 2010

\begin{tabular}{c|c}
\hline DEMOGRAPHIC CENSUS & TOTAL BRAZILIAN POPULATION \\
\hline 1940 & $41,236,315$ \\
\hline 1950 & $51,944,397$ \\
\hline 1960 & $70,992,343$ \\
\hline 1970 & $94,508,583$ \\
\hline 1980 & $121,150,573$ \\
\hline 1991 & $146,917,459$ \\
\hline 2000 & $169,590,693$ \\
\hline 2010 & $190,755,799$ \\
\hline
\end{tabular}

Organization and elaboration: Adriana Roseno Monteiro based on data from the IBGE demographic census.

So industrialization began to attract labor to the cities, thus provoking new configurations in the urban space. The increase in this urban population implied the need to expand the supply of urban services and equipment, as well as the provision of housing for the families. However, this did not take place at the same rate as the growth of cities. Brazilian urbanization, reinforced during the last decades, brought with it social problematics.

The process of intensified urbanization in the twentieth century evidenced the social inequality in Brazil, due to poor income distribution, leaving clear signs of the capitalist system expressed in the creation of spaces of exclusion and leading to the coining of terms such as social exclusion, precarious inclusion, territorial and environmental segregation, illegality and informality. (SANTOS, J. 2009).

It can be said, then, that in the last decades of the twentieth century, the national space has undergone profound transformations associated with social inequalities. Increasing urbanization coupled with the lack of necessary investments, together with the growth of cities has, however, brought the expansion of precarious housing settlements. This whole process resulted in changes in the urban structure of cities and changes in population's way of life, as these people, when arriving in the metropolis, were often inserted in a precarious and poorly paid way in productive activities and usually solved their housing problems through self-construction in generally informal, precarious and self-built housing in stages that make up favelas and irregular settlements or they started living in tenements.

Therefore, the way the urbanization process took place, together with the growth of the cities, entailed precarious housing conditions for man. This whole process resulted in changes in cities' urban structure and transformations in the population's way of life, as these areas were not prepared to house such a high number of people, neither were the industrial and service sectors able to absorb all of this population.

Social exclusion and precarious inclusion in the housing sector have been one of the hallmarks of the contemporary urbanization process, widening significantly in the last decades, when the lack of housing alternatives for the social segments on lower incomes resulted in the expansion of the more peripheral areas of the cities.

According to Maricato (2011), we have to take into account that the suburbs of the metropoles grew more than the central areas, resulting in the expansion of the poor regions. This is mainly due to rising land and housing prices in the most central and well-located areas of cities, leaving only the least valued and disadvantaged areas to the poor. 
The housing issue has become a problem linked to the accelerated urbanization process of cities, which were not prepared respond to such a large number of new residents, resulting in their disorderly expansion and affecting, above all, the working class, which due to the lack of resources began living in improvised, unhealthy and inadequate housing.

Therefore, the growth in the population living in urban areas requires a greater effort from public agencies to implement planning instruments, so as to articulate and ensure the orderly growth of cities, land use and occupation and meet the demand for public facilities for the population. However, this has not always been the case, in most Brazilian cities the urbanization model has produced spatial fragmentation and social disparity, resulting in problems such as unemployment, lack of urban services, lack of housing and other urban ills. Thus, the process of urbanization combined with inefficiency and, in many cases, the lack of public housing policies serving the economically disadvantaged social segments, were unable to meet the demand for housing.

\section{THE TRANSFORMATION OF URBAN LAND AND HOUSING INTO GOODS}

The capitalist city becomes the privileged place for the occurrence of a series of social processes, among which capital accumulation and its reproduction have basic importance. These processes create activities and their materialization, whose spatial distribution constitutes urban spatial organization itself.

Urban space and the use of urban land are destined to few, generating a growing mass of the excluded. So for this system to survive, it is necessary that many work for the few to enjoy their profits. The city is the product of class contradictions and involves diverse interests and needs.

Silva (1989) argues that it is the accommodation of basically economic interests that makes the capitalist city a socially constructed space that also shelters social classes with conflicting and antagonistic interests, transforming the urban into the privileged locus of capitalism and the class struggle.

As a socially constructed space, the city shelters diverse economic interests; it is the field of class struggles and the privileged location for the development of capitalism. The capitalist city is unequal, with totally different scenarios and antagonistic classes, housing is inserted in this context, therefore, it is situated within the social plots and class interests.

As a result, urban space, a product of human action, is marked by the divergent differences and interests of the social classes, one of the most relevant being the struggle for urban land and housing, creating a problem for those with few resources.

Urban land and housing are objects of generalized interest, involving social agents with or without capital, formally or informally organized, establishing a permanent tension, that varies in intensity, around urban land and housing. If this is not the basic contradiction, it becomes a problem for part of the population (CORRÊA, 2011).

Housing and urban land arouse the interest of all of society, because of this, it makes it difficult for the part of the population that does not have the financial resources to participate in this market. They are seen by many as a form of capitalist accumulation, since they are a commodity of extreme value, resulting in increasingly intense real estate speculation.

Land becomes an equivalent of capital and gains value, therefore, the search for profit is paramount. The increased value of land and housing happens thanks to the monopolization of access to this good that is vital for survival, and that becomes expensive and scarce in the capitalist reality.

According to Rodrigues (1991), in capitalist countries, including Brazil, urban land and buildings are integrated with the set of goods that are part of capitalist production. In this way, land becomes a commodity in the process of production of space and the reproduction of capital, the value of exchange becomes predominant in relation to the value of use. 
Space is then consumed as a commodity, so housing and urban land also form part of this process, where the value of use is replaced by the exchange value, real estate speculation contributes to price increases, greatly hampering the insertion of low-income families in the formal housing sector.

The commodification of urban housing and land and its transformation into a product determines urban land use, the expansion and organization of space, and remodels cities and focuses on an exclusive production of space.

To determine the price of housing the absolute and differential income of the land, the profits of the incorporation investments, the construction of the house and interest of the financial capital are summed, which will reach a very high amount that is inaccessible for most workers (RODRIGUES, 1991).

The price of urban land and housing, coupled with the high costs of the construction industry, interest on financing and the developers' profits lead to amounts that are inaccessible to the low income population and excludes them from the formal housing market.

Housing has a variable value and depends on its location. In general, central areas, spaces that are better supplied with public equipment and services, and which present positive aspects related to urbanity, neighborhood, environmental quality, urban mobility, security, among others, have high prices.

It is also observed that location is a determinant of the value of housing due to factors such as the distance from the work place, accessibility and ease of locomotion, access to services and infrastructure, neighborhood, quality of the environment, among others. The characteristics of the place are positive or negative externalities that can increase or depreciate the value of the properties in it. (ALMEIDA, 2011).

In this way, the price of land is defined by its location. This differentiation gives the landowner more real estate speculation and greater profits, further segmenting the space.

Urban land in a capitalist city, besides being a base for the reproduction of capital also serves as a reserve of value, a symbol of struggle and field of disputes. Due to real estate speculation we can observe several unoccupied plots of land spread through the city, especially in more strategic locations, waiting for price appreciation and consequently higher profits.

Urban land, in market economies, as well as a material support base for capital, is used as a reserve of value, giving rise to the process of real estate speculation, here understood as stocking lots and lands waiting for appreciation, permeating the urban fabric with immense voids and an unnecessary horizontal expansion. As a consequence, increased land values have been alarming, especially since the mid-1960s (SILVA, 1989, p.29).

Housing and urban land are governed by the norms of capital, so real estate speculation and urban land valuation allow developers to make greater profits, however, this entails an unnecessary horizontal expansion of the city and remodels the urban fabric in a segregating way.

According to Bassul (2002), the difficulty of access to land is a determinant of social deficiencies and inequalities. In cities, the high prices of urbanized land lead to population segregation by income strata, forcing many to seek shelter in distant areas with precarious public services and it is precisely the poorest who bear the highest costs of transportation and access to goods and services.

The construction of housing beyond the city limits is the result of a lack of adequate planning, which affects society as a whole, because in addition to burdening transport costs on those who need it most, they make infrastructure and urban mobility more expensive, congesting traffic and overburden public services, among others. 


\section{HOUSING AND SOCIAL INCLUSION}

Living somewhere is part of mankind's history, who has always sought a place to shelter from the cold, the rain, and ferocious animals, among other harsh conditions, in caves, tents, etc., that is, from its earliest form, the dwelling refers to the idea of a shelter against intruders, a place to protect oneself.

Therefore, man has always sought a place to shelter. That means that in some way people need somewhere to live. Therefore, housing is essential and everyone needs it, regardless of their social condition, so it must be understood as a product of a basic human need of every citizen.

Housing, being fundamental to our lives, is indispensable to the social reproduction of individuals (poor and rich); it is also the space of daily life and intimacy, the place where much of the human experience takes place (MEDEIROS, 2007, p.13).

An essential place for mankind, housing is therefore, a space to carry out day-to-day activities, a refuge for intimacy, providing greater security and a sense of well-being, enabling individuals and social groups to develop their capacities and carry out their most diverse desires.

The house plays a fundamental role in the realization of various activities that are essential to the social reproduction of individuals, to warmth, affectivity, impersonality and privacy, allowing the individual to be included in society; therefore, it is essential for human dignity.

According to Claval (2010), to inhabit does not only mean having a safe place from society, to live alone or as a family. It is also a place to meet people and lead a social life. The sphere that corresponds to the closest environment, that of the neighbors accessible in countries with dispersed dwelling, or the block and the neighborhood in cities.

Housing is a key place especially in the immediate sphere, that of family, neighbors and friends. It plays an essential role both for the individual and society in general, since it has a direct relation with how human beings survive.

The intrinsic peculiarities of the dwelling place it on a level of great relevance, being recognized as a social right. It is a determining factor of social inclusion, since besides offering shelter and the most varied possibilities of protection and security, it is the permanent stage of the daily life of its users.

However, because of the increase in urban land and housing, not everyone has access to this good, since land is a commodity and has a price that is defined by property and the buyers' ability to pay and not by their production; income is obtained from this good (RODRIGUES, 1991).

The rise in land prices as a result of increasingly intense real estate speculation has turned urban space into a scene of divergent disputes and interests, excluding the portion of the population that cannot afford the housing market. Thus, what should guarantee equality has revealed its most perverse side of social exclusion.

Given this commodification of urban land and housing, the low-income population has difficulty participating in this market by its own means, there is a lack of state intervention to provide housing, and not only housing, but also through the generation of employment and income, education, health, safety and other essential services, which are citizens' social rights.

Housing is an extremely important good and a right of every citizen. At the international level it appears as a right in Article $25^{1}$ of the Universal Declaration of Human Rights, adopted on December 10, 1948, by the General Assembly of the United Nations.

In the national context, we can point to two legal frameworks that bring legal guarantees to

(1) Article 25 of the 1948 UN Declaration of Human Rights states: "1. Everyone has the right to a standard of living adequate for the health and well-being of themselves and their family, including food, clothing, housing, medical care and essential social services, and the right to safety in the event of unemployment, sickness, disability, Widowhood, old age or other cases of loss of livelihood beyond their control." 
housing. The first is the Federal Constitution of 1988, mainly in article $6^{2}$ that includes housing as one of the social rights and articles 182 and 183 that aim to guide urban policy.

The second is Law n. 10,257 of July 10, 2001, called the Statute of the City, which regulated the chapter on Urban Policy (arts. 182 and 183) of the Federal Constitution of 1988, with the objective of ordering the full development of the social functions of the city and urban property, establishing rules of public order and social interest that regulate the use of urban property for the collective good, security and the well-being of citizens, as well as environmental balance.

Therefore, access to housing, as well as being a necessity, is also a right of every citizen, however, the acquisition of housing for the low-income class is related to a series of difficulties, including social inequality, exclusionary housing policies, lack of employment, and poor distribution of income, among others (MARTINS, 2007)

The lack of financial resources of one part of the population will be reflected in the forms of people's habitations, often characterized by irregular occupation of public and private spaces and fragile environmental areas such as river banks and slopes, resulting in the disordered expansion of the city, a reflection of social inequality and exclusion.

This is when it has been possible to find a place to live, because many are totally destitute, living in squares, under bridges and viaducts, and subject to the most diverse situations of risk. This problem is ignored by those who should guarantee citizens' basic rights and a lack of more energetic interventionist public policies.

As an example, we can mention the policy of social inclusion carried out in the city of Lisbon in Portugal, in which the government has undertaken a National Strategy through a set of measures to create conditions to monitor risk situations and prevent the loss of housing, and ensuring that no one has to remain without decent housing.

The National Strategy operates at three levels: prevention, covering all risk groups; emergency / intervention, working with the homeless population, creating conditions so that no citizen has to become or remain homeless, nor stay in the street for more than 24 hours. It also ensures that no one has to remain in temporary accommodation indefinitely and that access to social rights is guaranteed for all citizens, as well as the full exercise of citizenship. (Lúcio and Marques, 2010)

In Brazil, the housing policy effectively started in 1964, with the creation of the National Housing Bank (BNH). During the period of the BNH (1964-1986) financing for low-income families was carried out by COHABs (Housing Companies).

Despite improvements in the housing sector, $\mathrm{COHABs}$ cannot be considered as a policy of social inclusion, since although initially they focused families with incomes of less than three minimum wages, they later began to prioritize the population with an income above three to five minimum wages, thus undermining their initial goal. This was mainly due to the high default rate in the range of up to three minimum wages.

More recently the Minha Casa, Minha Vida (PMCMV) Program, was launched in 2009, aimed at low-income families, where significant subsidies are being offered for the acquisition of a home.

PMCMV 1 (one), the initial phase, from 2009 to 2011, had the goal of constructing one million housing units in the short term, having allocated R $\$ 34$ billion (R $\$ 25.5$ billion from the of the General Budget of the Union, R 7.5 billion from FGTS - severance pay indemnity fund, and R\$ 1 billion from BNDES - National Bank for Economic and Social Development).

(2) The art. 6 of the Federal Constitution was amended by Constitutional Amendment n. 26, dated February 14, 2000, which was replaced by the following: "Social rights are education, health, work, housing, leisure, security, social security, maternity and child protection, assistance to the homeless, in the form of this Constitution." 
As already mentioned, this program aims to serve families earning up to 10 minimum wages, distributed as follows: 400 thousand housing units (UHS) for families that fall in the income range 1 (one) that is from zero to 3 minimum wages; 400 thousand UHS for families that fall within the range of income 2 (two) which is between 3 to 6 minimum wages and 200 thousand UHS for families in income range 3 (three) which is from 6 to 10 minimum wages.

In 2010 the goal of 1 million built dwellings had been achieved by PMCMV phase 1 (one). Therefore, in June 16, 2011, under the government of Dilma Rousseff (2011-2014) the second phase of the PMCMV was officially launched, i.e., PMCMV 2 (two), in which new rules were added to the program.

The PMCMV 2 (two), 2011 to 2014, aimed to build 2 million homes with an investment of R\$ 71.7 billion by 2014, R $\$ 62.2$ billion from the General Budget of the Union and $\mathrm{R} \$ 9.5$ billion from the FGTS. It covers state capitals and their metropolitan areas, the Federal District and municipalities with populations equal to or greater than 50 thousand inhabitants. It can also serve municipalities with a population between 20 and 50 thousand inhabitants if they meet some requirements: an urban population greater than or equal to $70 \%$; a population growth rate of more than $5 \%$ between the period 2007 to 2010 and a rate of population growth which is higher than the rate recorded in the state in question in the period 2000-2010.

In this second phase of the PMCMV, there were changes in the income range, which are now related to fixed values: income range 1 (one) - includes families with incomes up to $\mathrm{R} \$ 1,600.00$, which in phase 1 (a) of the Program was from zero to three minimum wages; Income range 2 (two) - families with an income from $R \$ 1,600.00$ to $R \$ 3,100.00$, which in phase 1 (one) was above three to six minimum wages; and income bracket 3 (three) - families with incomes above R $\$ 3,100.00$ to $\mathrm{R} \$ 5,000.00$, which in phase 1 (one) of the PMCMV was above six to ten minimum wages.

There have also been changes in the distribution of UHS by income bracket. Of the 2 million housing units: $60 \%$ of the total, that is, 1.2 million are for families in band 1 (one) - up to R \$ $1,600.00 ; 30 \%$ of the total, or 600 thousand UHS, will include the families in band 2 (two) - above R \$ $1,600.00$ up to R $3,100.00$ and $10 \%$ or 200 thousand UHS will benefit the families in band 3 (three) - above $\mathrm{R} \$ 3,100.00$ to $\mathrm{R} \$ 5,000.00$.

The data above reveal that the PMCMV represents advances in the housing issue in Brazil, taking into account that it is a recent program and is still under way, and that in this short period of time the amount of the subsidy for the housing sector has increased considerably and enabled the construction of a significant number of dwellings for the low-income population; thus it has emerged as a conquest for the right to housing.

According to UN estimates, about 100 million people worldwide have nowhere to live and more than 1 billion do not have adequate housing. If nothing is done to improve the situation, by 2050 the number could reach three billion people living in precarious settlements. In Brazil, these data are also not very encouraging, because according to the Institute of Applied Economic Research-IPEA (2013) the housing deficit in Brazil in 2012 was 5.24 million households.

Urban land as well as housing are a high value good, generating diverse interests and benefiting those who have more resources. Given this situation, owning a home becomes a problem for families with lower purchasing power, since they cannot compete equally with other social actors.

This part of the population that cannot participate in the housing market with its own resources needs interventions by the public sector through well-developed housing policies, that is, with an efficient and effective action that can solve the housing issue, so as to take into account the extent of the social problems found in the Brazilian reality and overcome this situation of social exclusion.

In the light of these discussions, it is essential to highlight the relevance of ecological alternatives for the housing sector, especially for low-income families, since they aim to design low-cost housing with a reduced energy consumption. These sustainable constructions take into account 
ecological principles and the efficient use of resources, reducing consumption, maximizing and reusing natural resources, and using recyclable materials to protect the environment.

In Brazil the City of Belo Horizonte develops a successful recycling program, using $90 \%$ of the waste from a recycling center. These recycled public houses, as they are called, would take less than a third of the time to be built and would cost $35 \%$ less than the classic houses in present day housing developments (FITTIPALDI, 2008).

These ecological alternatives can use various types of materials, such as unprocessed waste, materials like PET bottles, car tires, cans, paper bricks, sustainable industrial materials, reusable materials, materials found on the market and assigned new functions, materials found in nature, ${ }^{3}$ etc..

Within the scope of Brazilian federal policies there has not yet been any housing program aimed at the construction of ecological alternative houses. However, it could be a strategy for building "future" public housing with the premise of social inclusion, but much discussion is still needed.

Social inclusion and the fight against poverty must go through the provision of adequate housing for the population, since it is a good with a strong impact on reducing poverty, improving well-being and the quality and life in general. In addition, the housing sector produces quite positive effects on the economy, it is capable of generating employment and income, especially for the low-skilled work that normally characterizes the poorest population (ALMEIDA, 2011).

Adequate housing is one of the steps for social inclusion and for combating poverty and is directly related to the quality of life of the population, their well-being and social equity. It is a way for the citizen to be inserted in the city and society and one of the steps to ensure their equality.

Therefore, a well-developed housing policy focused on providing housing for the lower-income segments of the population, with the provision of essential public services and the generation of employment and income, among many others, is fundamental to ensure the minimum conditions for citizenship and social inclusion.

\section{FINAL CONSIDERATIONS}

The problem of housing in Brazil, especially for disadvantaged populations, has historically been linked to the growth of cities. The population, especially since 1940, has sought the urban centers with greater intensity as a result of the rural exodus, the migrations and the desire of the population for better living conditions.

The intensity of Brazilian urbanization and the lack of urban planning have had some consequences, such as problems of urban mobility, congestion and the scrapping of public transport, basic sanitation with inadequate water and sewage treatment and distribution services. Urban violence, environmental and noise pollution, homelessness and irregular occupations are among other social problems that affect urban centers.

The housing issue is complex and the increase or decrease of its supply in the market depends on several factors, among them, real estate speculation, housing prices, population income, housing typologies, location, the population growth rate, access to financing and current public housing policies. All these factors will influence the acquisition of housing by families.

We must not forget that a housing policy based on social inclusion will provide access to housing not only by taking quantitative aspects into account and reducing the housing problem only to the numbers of houses, but also ensuring inclusion in the city through adequate infrastructure, health services, education, security, leisure, urban mobility, and employment and income, among others, that will provide these individuals with a more dignified life.

(3) These houses built with materials found in nature are called natural constructions, they are low cost and are appropriate for sites integrated with nature and vegetation. 
The provision of housing for low-income families through public housing policies is essential for social development and the fight against poverty. Every citizen needs a place to live and needs their rights to be respected, with regard to social, economic, political, and cultural aspects, among others.

The reduction of social inequalities and the search for equity permeate the effectiveness and efficacy of public housing policies that are capable of solving the lack and the precariousness of housing and offer other public services essential to citizens, allied with other public policies of promotion and development that guarantee individuals a better quality of life.

As a result, an effective housing policy, besides elaborating action diagnostics, must also anticipate problems, carry out a critical evaluation of programs' performance, analyze their implications for the population and on urban spaces, thus enabling an efficient implementation.

\section{BIBLIOGRAPHIC REFERENCES}

ALMEIDA, Isaura Florisa Gottschall de. Desigualdades e políticas públicas de habitação no Brasil. 2011. 158p. Dissertação (Mestrado em Economia) - Faculdade de Ciências Econômicas, Universidade Federal da Bahia, Salvador, 2011.

BASSUL, José Roberto. Reforma urbana e Estatuto da Cidade. Revista Latino Americana de Estudos Urbanos Regionais - EURE. n. 84, v. 28. Santiago, 2002. Disponível em: http://www.scielo.cl/scielo. Acesso em: 16/01/2015.

BRASIL. Constituição (1988). Constituição da República Federativa do Brasil: promulgada em 05 de outubro de 1988. Disponível em: <http://www.planalto.gov.br/ccivil_03/Constituicao/Constituicao.htm>. Acesso em: 10/01/15.

BRASIL. Lei n. 10.257, de 10 de julho de 2001. Regulamenta os arts. 182 e 183 da Constituição Federal, estabelece diretrizes gerais da política urbana e dá outras providências. Diário Oficial da União, Brasília, DF, 11 de jul. de 2001. Disponível em: <http://www.planalto.gov.br/ccivil_03/Leis/LEIS_2001/L10257. htm>. Acesso em: 10/01/15.

CLAVAL, Paul. Terra dos homens: a Geografia. Traduzido por Domitila Madureira. São Paulo: Contexto, 2010. 143p.

CORRÊA, Roberto Lobato. Sobre agentes sociais, escala e produção do espaço: um texto para discussão. In:CARLOS, Ana Fani Alessandri; SOUZA, Marcelo Lopes de; SPOSITO, Maria Encarnação Beltrão (org.). A produção do espaço urbano: agentes e processos, escalas e desafios. São Paulo: Contexto, 2011. p. 41-51. FITTIPALDI, Mônica. Habitação social e Arquitetura sustentável em Ilhéus/BA. 2008. 136p. Dissertação (Mestrado em Desenvolvimento Regional e Meio Ambiente) - Pós-Graduação em Desenvolvimento Regional e Meio Ambiente, Universidade Estadual de Santa Cruz, Ilhéus-BA, 2008.

IBGE. Instituto Brasileiro de Geografia e Estatística. Censos Demográficos 1940 a 2010. Roraima. Disponível em: <http://www.ibge.gov.br>. Acesso em: 15/01/2015.

LÚCIO, José; MARQUES, Filomena. Inclusão Social-do conceito à estratégia: o caso dos sem-abrigo na Cidade de Lisboa. Actas do Seminário Geografias de Inclusão: desafios e oportunidades, Lisboa: Faculdade de Ciências Sociais e Humanas, Universidade Nova de Lisboa, p.01-24, dez. de 2010.

MARICATO, Ermínia. Brasil, cidades: alternativas para a crise urbana. $4^{\mathrm{a}}$ ed. Petrópolis, RJ: Vozes, 2011. 204p.

MARTINS, Victor Hugo Teixeira. Habitação, infra-estrutura e serviços públicos: Conjuntos habitacionais e suas temporalidades em Londrina - PR. 2007. 175p. Dissertação (Mestrado em Geografia, Meio Ambiente e Desenvolvimento), Programa de Pós-Graduação em Geografia, Meio Ambiente e Desenvolvimento do Departamento de Geociências, Universidade Estadual de Londrina, Londrina, 2007.

MEDEIROS, Sara Raquel Fernandes Queiroz de. A casa própria: Sonho ou realidade?Um olhar sobre os conjuntos habitacionais em Natal. 2007. 111p. Dissertação (Mestrado em Ciências Sociais) - Centro de Ciências Humanas letras e artes, Universidade Federal do Rio Grande do Norte, Natal, 2007. 
VICENTE NETO, Correia Lima; FURTADO, Bernardo Alves; KRAUSE, Cleandro. Nota Técnica Estimativas do déficit habitacional brasileiro (PNAD 2007 - 2012). IPEA, 2013. 17p.

ONU. Declaração Universal dos Direitos Humanos. Adotada e proclamada pela resolução 217A (III) da Assembleia Geral das Nações Unidas em 10 de dezembro de 1948. Disponível em: <http://portal.mj.gov. $\mathrm{br} / \mathrm{sedh} / \mathrm{ct} /$ legis_intern/ddh_bib_inter_universal.htm>. Acesso em: 10/02/15.

ONU. Programa das Nações Unidas para os assentamentos Humanos ONU-HABITAT. Disponível em: $<\mathrm{http}$ //www.onu.org.br/onu-no-brasil/onu-habitat/>. Acesso em:12/02/15.

ONU. Consejo Económico y Social. Los derechos económicos, sociales y culturales. E/CN.4/2005/48, p. 01-26. Distr. General, mar. de 2005. Disponível em:<http://direitoamoradia.org/wp-content/uploads/2013/08/ relat\%C3\%B3rio_semteto_ES.pdf $>$. Acesso em: 20/02/15.

RODRIGUES, Arlete Moysés. Moradia nas cidades brasileiras. $4^{\mathrm{a}}$ ed. São Paulo: Contexto, 1991. 72p. SANTOS, Joyce Costa. A percepção dos atores sociais frente à intervenção pública: uma análise sociológica do conjunto habitacional Vargem Grande. 2009. 106p. Dissertação (Mestrado em Desenvolvimento Social), Programa de pós- graduação em desenvolvimento social, Universidade Estadual de Montes Claros. Montes Claros-MG, 2009.

SANTOS, Milton. A Urbanização Brasileira. $5^{\text {a }}$ ed. São Paulo: Editora da Universidade de São Paulo, 2009. 176p.

SANTOS, Milton. Metamorfoses do Espaço Habitado. São Paulo: Hucitec, 1994. 136p.

SILVA, Maria Ozanira da Silva e. Política habitacional brasileira: verso e reverso. São Paulo: Cortez editora, 1989. 199p.

SOUZA, Barbara Cecilia Machado Fontes. Desenvolvimento regional e gestão metropolitana: reflexões a partir da política habitacional na região metropolitana de Aracaju. 2009. 140p. Dissertação (Mestrado em Desenvolvimento Regional e Gestão de Empreendimentos locais) - Núcleo de Pós-Graduação e Pesquisa em economia, Universidade de Sergipe, São Cristovão, 2009.

SOUZA, Marcelo Lopes de. ABC do desenvolvimento urbano. $6^{\text {a }}$ Ed. Rio de Janeiro: Bertrand Brasil, 2011. 192p. 